\title{
The C Proteins of HeLa 40S Nuclear Ribonucleoprotein Particles Exist as Anisotropic Tetramers of $(\mathrm{C} 1)_{3} \mathrm{C} 2$
}

\author{
STANLEY F. BARNETT, DANIEL L. FRIEDMAN, AND WALLACE M. LESTOURGEON* \\ Department of Molecular Biology, Vanderbilt University, Nashville, Tennessee 37235
}

Received 6 June 1988/Accepted 4 November 1988

\begin{abstract}
The $\mathrm{C}$ proteins (C1 and $\mathrm{C2}$ ) of HeLa $40 \mathrm{~S}$ heterogeneous nuclear ribonucleoprotein particles copurify under native conditions as a stable complex with a fixed molar protein ratio (S. F. Barnett, W. M. LeStourgeon, and D. L. Friedman, J. Biochem. Biophys. Methods 16:87-97, 1988). Gel filtration chromatography and velocity sedimentation analyses of these complexes revealed a large Stokes radius $(6.2 \mathrm{~nm})$ and a sedimentation coefficient of 5.8S. On the basis of these values and a partial specific volume of $0.70 \mathrm{~cm}^{3} / \mathrm{g}$ based on the amino acid composition, the molecular weight of the complex was calculated to be 135,500 . This corresponds well to 129,056 , the sequence-determined molecular weight of a $(\mathrm{C} 1)_{3} \mathrm{C} 2$ tetramer. Reversible chemical cross-linking with dithiobis(succinimidyl propionate) and analysis of cross-linked and cleaved complexes in sodium dodecyl sulfate-polyacrylamide gel electrophoresis confirmed that the $\mathbf{C}$ proteins exist as tetramers, most or all of which are composed of $(\mathrm{C1})_{3} \mathrm{C2}$. The tetramer is stable in a wide range of $\mathrm{NaCl}$ concentrations $(0.09$ to $2.0 \mathrm{M})$ and is not dissociated by $0.5 \%$ sodium deoxycholate. This stability is not the result of disulfide bonds or interactions with divalent cations. The hydrodynamic properties of highly purified $\mathrm{C}$-protein tetramers are the same for C-protein complexes released from intact particles with RNase or high salt. These findings support previous studies indicating that the core particle protein stoichiometry of $40 S$ heterogeneous nuclear ribonucleoproteins is $\mathbf{N}(3 \mathrm{A1}-3 \mathrm{A2}-1 \mathrm{B1}-1 \mathrm{~B} 2-3 \mathrm{C1}-1 \mathrm{C2})$, where $\mathrm{N}=3$ to 4 , and demonstrate that the $\mathrm{C}$-protein tetramer is a fundamental structural element in these RNA-packaging complexes. The presence of at least three tetramers per $40 \mathrm{~S}$ monoparticle, together with the highly anisotropic nature of the tetramer, suggests that one-third of the 700-nucleotide pre-mRNA moiety packaged in monoparticles is associated through a sequence-independent mechanism with the $C$ proteins.
\end{abstract}

In mammalian cells, pre-mRNA is packaged during transcription by multiple copies of a few abundant nuclear proteins to form a repeating array of regular $40 \mathrm{~S}$ heterogeneous nuclear ribonucleoprotein particles (hnRNP) $(11,13$, 15,22 ; W. M. LeStourgeon, S. F. Barnett, and S. J. Northington, in S. H. Wilson, ed., The eukaryotic nucleus, in press). When isolated from sucrose density gradients, $40 \mathrm{~S}$ monoparticles possess an ultrastructural morphology indistinguishable from that seen in gently spread transcriptive units (38) and are composed primarily of multiple copies of six major core particle proteins $(5,7,14,24,25,27,40)$ and a 700-nucleotide fragment of RNA (13). The proteins migrate in single-dimension sodium dodecyl sulfate-polyacrylamide gel electrophoresis (SDS-PAGE) as three groups of doublet bands (A1-A2, B1-B2, and C1-C2 doublets) with apparent molecular masses of 32 to 44 kilodaltons (5). Studies with protein-cross-linking reagents have indicated that the basic molar ratio of the core proteins in particles from rapidly dividing HeLa cells is 3A1-3A2-1B1-1B2-3C1-1C2 (27). When antibodies to the core particle proteins are used to isolate hnRNP complexes, several additional proteins are observed, and among these, polypeptides of 68 and 120 kilodaltons have been identified as in vivo components of hnRNP complexes (32).

Interest in the composition and structure of hnRNP complexes and in the role of individual core particle proteins is derived from the large body of evidence indicating that RNA splicing occurs while transcripts exist in a packaged state (3, $4,15,22,30)$. More specifically, monoclonal antibodies to the $\mathrm{C}$ proteins inhibit in vitro splicing of an adenovirus transcript and immunoprecipitate the $60 \mathrm{~S}$ splicing complex

\footnotetext{
* Corresponding author.
}

(i.e., the spliceosome) (9). Similarly, polyclonal antibodies to the core particle proteins completely inhibit splicing of human $\beta$-globin transcripts in vitro (35). Moreover, immunoadsorption of the $C$ proteins from splicing extracts prevents spliceosome formation and results in loss of splicing activity (9). These observations have suggested an essential role for $\mathrm{C}$ proteins in the splicing of pre-mRNA transcripts.

Further interest in $\mathrm{C}$ proteins is derived from the recent but different findings of two research groups. Goswami and Goldenberg (20) report that the $\mathrm{C}$ proteins present in HeLa nuclear extracts bind mouse RNA in a length- but not sequence-dependent fashion and that binding is dependent on the presence of introns, $\mathrm{Mg}^{2+}$, and ATP. Swanson and Dreyfuss (36), who used similar nuclear extracts, reported that the $\mathrm{C}$ proteins specifically bind to the polypyrimidine sequence at the $3^{\prime}$ end of introns in transcripts of the human $\beta$-globin and adenovirus genes. It was also reported that $C$ protein failed to bind a bacterial and intronless spliced product and that ATP is not required for sequence-specific binding. Previous studies on the in vitro assembly of $40 \mathrm{~S}$ monoparticles and polyparticle complexes have shown that correct particle assembly is dependent on RNA length but not on the presence of eucaryotic RNA-processing signals $(13,33,39)$. RNA or single-stranded DNA substrates of nearly 700 nucleotides support the assembly of $40 \mathrm{~S}$ monoparticles, and multiples of this length support the assembly of dimers and polyparticle complexes (13).

We have previously reported a rapid three-step procedure for the purification of native $\mathrm{C}$ protein from isolated HeLa 40S hnRNP particles (2). Proteins $C 1$ and $C 2$ copurified in a fixed molar ratio and eluted from analytical gel filtration columns with an apparent mass greater than that of apoferritin $\left(M_{\mathrm{r}}, 443,000\right)$. In this report, we show that C-protein 
complexes exist in monoparticles and in solution as stable, highly anisotropic heterotetramers composed of $\mathrm{C} 1$ and $\mathrm{C} 2$ in a 3:1 ratio. These findings partially confirm previous studies indicating that core particle protein stoichiometry is $\mathrm{N}(3 \mathrm{~A} 1-3 \mathrm{~A} 2-1 \mathrm{~B} 1-1 \mathrm{~B} 2-3 \mathrm{C} 1-1 \mathrm{C} 2)$, where $\mathrm{N}=3$ or 4 (27). The presence of at least three $\mathrm{C}$-protein tetramers per monoparticle, the absence of reiterated sequences in the 700-nucleotide length of packaged pre-mRNA, and the potential for C-protein tetramers to bind relatively long lengths of RNA suggest a fundamental sequence-independent RNA-binding mechanism for most if not all of $40 \mathrm{~S}$ monoparticle-associated C-protein.

\section{MATERIALS AND METHODS}

Cell culture, hnRNP particle isolation and C-protein purification. The methods used for cell culture, hnRNP particle isolation, and C-protein purification have been described in detail previously $(2 ;$ S. F. Barnett, S. J. Northington, and W. M. LeStourgeon, Methods Enzymol., in press). Briefly, nuclei were isolated from exponentially growing HeLa cells. Monomer 40S hnRNP particles were isolated from nuclear sonicates by sedimentation on 15 to $30 \%$ sucrose gradients. To isolate C-protein-RNA complexes, monoparticles were adjusted to $350 \mathrm{mM} \mathrm{NaCl}$ and chromatographed on Bio-Gel A0.5M in $350 \mathrm{mM} \mathrm{NaCl}$. The C-protein-RNA complexes in the void volume were adjusted to $10 \%$ glycerol and $1 \mathrm{mM}$ dithiothreitol, and the RNA was removed by extensive digestion with either micrococcal nuclease (Boehringer Mannheim Biochemicals) or RNase A (Worthington Diagnostics). Final C-protein purification was by anion-exchange chromatography on a Mono $Q$ column (Pharmacia Fine Chemicals) with an $\mathrm{NaCl}$ gradient. Proteins $\mathrm{C} 1$ and $\mathrm{C} 2$ coeluted in $480 \mathrm{mM} \mathrm{NaCl}$. C-protein purity was greater than 95\%, as judged by SDS-PAGE (2).

Gel filtration chromatography. Gel filtration chromatography was performed on Bio-Gel A1.5M $(1.0 \mathrm{~cm}$ [inside diameter] by $75 \mathrm{~cm})$, Bio-Gel P-300 $(1.0 \mathrm{~cm}$ [inside diameter] by $75 \mathrm{~cm})$, and Superose $6(1.0 \mathrm{~cm}$ [inside diameter] by 30 $\mathrm{cm})$ columns. Buffers contained $20 \mathrm{mM}$ Tris hydrochloride (pH 8.0), $1.0 \mathrm{mM} \mathrm{MgCl}$, and other components, as indicated. The Bio-Gel A1.5M, Bio-Gel P-300, and Superose columns were eluted at 5,2 , and $12 \mathrm{ml} / \mathrm{h}$, respectively. Void volumes and total column volumes were determined with Dextran Blue 2000 and Phenol Red. The protein standards (and their Stokes radii) used to calibrate the gel filtration columns were bovine thyroglobulin $(8.1 \mathrm{~nm})$, bovine immunoglobulin G $(5.22 \mathrm{~nm})$, and bovine serum albumin (BSA) $(3.5 \mathrm{~nm})$. Protein standards were chromatographed before and after the C-protein complexes to ensure accurate comparisons of elution volumes. In some experiments, hnRNP particles were digested $\left(0^{\circ} \mathrm{C}\right.$ for $\left.1.5 \mathrm{~h}\right)$ with $10 \mu \mathrm{g}$ of RNase A per $\mathrm{ml}$ or $50 \mathrm{U}$ of micrococcal nuclease per $\mathrm{ml}$ before chromatography.

Sucrose density gradient centrifugation. The conditions of centrifugation and determination of sedimentation coefficients were as described by Martin and Ames (29). Sucrose gradients ( 5 to $20 \%$ ) were prepared in $20 \mathrm{mM}$ Tris hydrochloride ( $\mathrm{pH}$ 8.0)-1 mM dithiothreitol-1 mM MgCl $\mathrm{m}_{2}$. Other components were varied as described in Results. $\mathrm{MgCl}_{2}$ was omitted when deoxycholate (DOC) was present. The gradients were centrifuged at $188,753 \times g$ for $28 \mathrm{~h}$ at $4^{\circ} \mathrm{C}$. Samples $(0.5 \mathrm{ml})$ were loaded onto $11.5-\mathrm{ml}$ gradients. Bovine immunoglobulin G (7.0S) and BSA (4.3S) were used as standards. Fractions were collected, trichloroacetic acid or ethanol precipitated, and subjected to SDS-PAGE.
Cross-linking with DSP. Purified C protein (1 to $2 \mathrm{ml})$ was dialyzed against 1.0 liter of cross-linking buffer $(10 \mathrm{mM}$ sodium phosphate buffer [pH 7.3], $100 \mathrm{mM} \mathrm{NaCl}$ ) for $14 \mathrm{~h}$ at $4^{\circ} \mathrm{C}$. Dithiobis(succinimidyl propionate) (DSP) was freshly prepared by adding $8.0 \mathrm{mg}$ to $1.0 \mathrm{ml}$ of $N^{\prime}, N^{\prime}$-dimethylformamide at $0^{\circ} \mathrm{C}$. This stock solution was further diluted in cross-linking buffer and added to an equal volume of $\mathrm{C}$ protein $(20 \mu \mathrm{g} / \mathrm{ml})$ at $0^{\circ} \mathrm{C}$. After incubation $\left(0^{\circ} \mathrm{C}, 10\right.$ to 30 $\mathrm{min}$ ), the solution was adjusted to $40 \mathrm{mM}$ lysine by addition of a $1.0 \mathrm{M}$ stock solution ( $\mathrm{pH} 7.5$ ). After $10 \mathrm{~min}$, the solution was adjusted to $20 \mathrm{mM} N$-ethylmaleimide by addition of a fresh $0.5 \mathrm{M}$ stock solution in $80 \%$ ethanol. The protein was ethanol precipitated, and the pellet was washed twice with $70 \%$ ethanol before addition of electrophoresis sample buffer. Before electrophoresis, the sample was incubated at $37^{\circ} \mathrm{C}$ for $30 \mathrm{~min}$. DSP cross-links were cleaved by being heated to $100^{\circ} \mathrm{C}$ for $2 \mathrm{~min}$ in sample buffer containing $0.1 \%$ $\beta$-mercaptoethanol (BME).

Protein determination and SDS-PAGE. Protein was determined by a microassay technique (31) adapted from the method of Lowry et al. (28), with BSA as the standard. Peak fractions of specific proteins in gel filtration or density gradient sedimentation experiments were determined by the method of Fenner et al. (18). This method is based on the spectrophotometric quantitation of Coomassie blue eluted from excised protein bands after separation by SDS-PAGE. SDS-PAGE was by the method of Laemmli (23).

\section{RESULTS}

We have recently described a simple protocol for the purification of native $\mathrm{C}$ protein from isolated HeLa cell $40 \mathrm{~S}$ hnRNP particles (2). In those studies, it was observed that $C$ protein elutes from Superose 6 gel filtration columns as a complex composed of $\mathrm{C} 1$ and $\mathrm{C} 2$ with an apparent mass greater than that of apoferritin $\left(M_{r}, 443,000\right)$. This phenomenon has now been observed with Superose 6 at salt concentrations as high as $2.0 \mathrm{M}$ and with Bio-Gel P columns at salt concentrations as low as $0.1 \mathrm{M}$. In these studies, it was observed that if $\mathrm{C}$ protein devoid of its RNA substrate was applied to agarose-based matrices (Superose 6 or Bio-Gel A1.5M) at salt concentrations below $0.5 \mathrm{M}$ it could not be eluted at salt concentrations as high as $2 \mathrm{M}$. This problem was not encountered with acrylamide-based gel filtration media such as Bio-Gel P. Analysis of the gel filtration data by the method and equations of Ackers (1) yielded a Stokes radius of $6.2 \mathrm{~nm}$ for the C-protein complex. The large Stokes radius suggests either a spherical structure containing more than $15 \mathrm{C}$-protein monomers or an anisotropic structure containing fewer polypeptides. We distinguished between these two possibilities and defined the protein stoichiometry of the C-protein complex as described below.

The sedimentation coefficient $\left(s_{20, n}\right)$ of the purified Cprotein complex was determined by cosedimentation with BSA (4.3S) and immunoglobulin G (7.0S) in 5 to $20 \%$ sucrose density gradients by the procedures of Martin and Ames (29) (Fig. 1). Identical results were obtained at salt concentrations of $0.09,0.5,1.0$, and $2.0 \mathrm{M}$. These experiments were conducted in buffers identical to those used for the gel filtration studies. To exclude the possibility that sucrose has an effect on the composition of the C-protein complex, the gel filtration experiments were repeated with buffers containing $10 \%$ sucrose. No change in the elution profile was observed (data not shown). On the basis of an analysis of the data in Fig. 1, we define the sedimentation coefficient of the C-protein complex as $5.8 \mathrm{~S}$. 


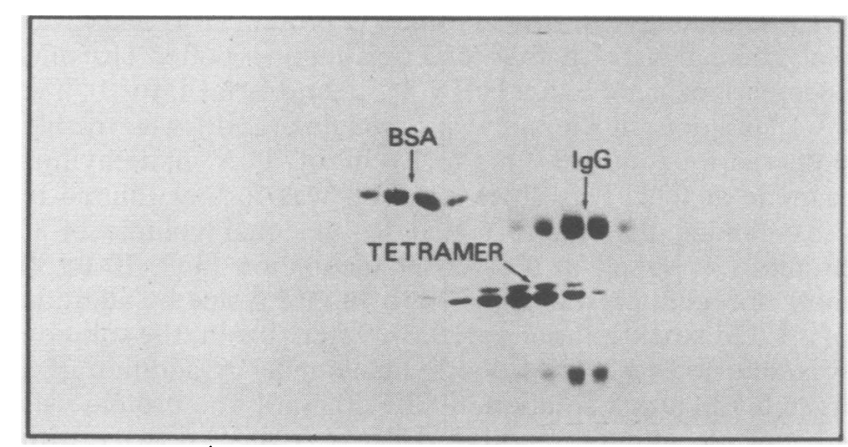

FIG. 1. Sedimentation of purified C protein. Purified $C$ protein was combined with BSA $(67 \mathrm{kDa})$ and gamma globulin $(150 \mathrm{kDa})$ and cosedimented in a 5 to $20 \%$ sucrose density gradient as described in Materials and Methods. The sample and gradient contained $0.5 \% \mathrm{M}$ $\mathrm{NaCl}$. (A) Coomassie blue-stained SDS-PAGE gel showing the distribution of the proteins in the gradient. The peak fractions for each protein were determined by measuring the $A_{600}$ of dye eluted from excised bands. (B) The relative absorbances of the proteins present in each fraction are plotted. The sedimentation coefficient of the C-protein complex was determined to be 5.8, as described in Materials and Methods.

The partial specific volume of the $\mathrm{C}$ proteins was calculated by the method of Cohn and Edsall (12) on the basis of the sequence-deduced amino acid composition (37). The same value was assumed for both $\mathrm{C} 1$ and $\mathrm{C} 2$, since they appeared to be extremely similar (8). On the basis of the values obtained for the Stokes radius $(6.2 \mathrm{~nm})$, the sedimentation coefficient $(5.8 \mathrm{~S})$, and the partial specific volume $(0.70$ $\mathrm{cm}^{3} / \mathrm{g}$ ), the molecular weight and frictional ratio were calculated to be 135,500 and 2.0, respectively (Table 1). Given the monomer molecular weight of 31,931 (37), these values are most consistent with a tetrameric C-protein complex.

If isolated 40S hnRNP particles are digested with RNase or adjusted to $1.0 \mathrm{M} \mathrm{NaCl}$, the particle proteins dissociate into low-molecular-weight species $(5,13,25,27,34)$. The C-protein complexes released from particles by these methods have the same hydrodynamic properties as purified $\mathrm{C}$ protein. An SDS-PAGE gel showing the sedimentation profile of nuclease-dissociated $40 \mathrm{~S}$ particle proteins is shown in Fig. 2. A protein with the same electrophoretic mobility as $\mathrm{C} 2$ dissociated as did the other particle proteins and sedimented in the upper gradient regions as a monomer (Fig. 2). Unlike proteins $\mathrm{C} 1$ and $\mathrm{C} 2$, this protein does not bind RNA in a salt-resistant manner and does not copurify with the C-protein complex (2). We (5) and other investigators (32, 40), using two-dimensional gels, have noted the presence of

TABLE 1. Physical properties of the C-protein tetramer

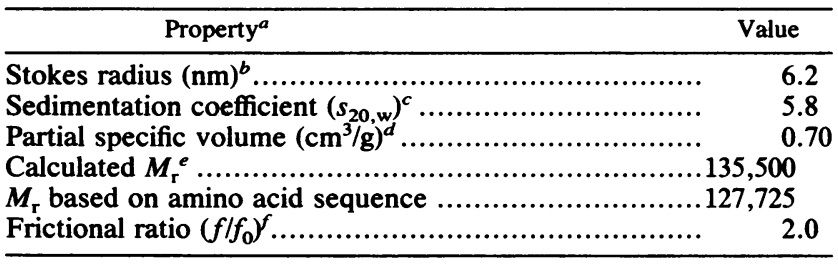

a Stokes radius, sedimentation coefficient, and partial specific volume were determined as described in Materials and Methods.

$b$ Based on gel filtration on Superose 6.

c Based on sedimentation on 5 to $20 \%$ sucrose gradients.

${ }^{d}$ Estimated on the basis of amino acid composition.

e Calculated by the equation $M=6 \pi n N a s /(1-v p)$.

$f$ Calculated by the equation $f / f_{0}=a /(3 v M / 4 \pi N)^{1 / 3}$.

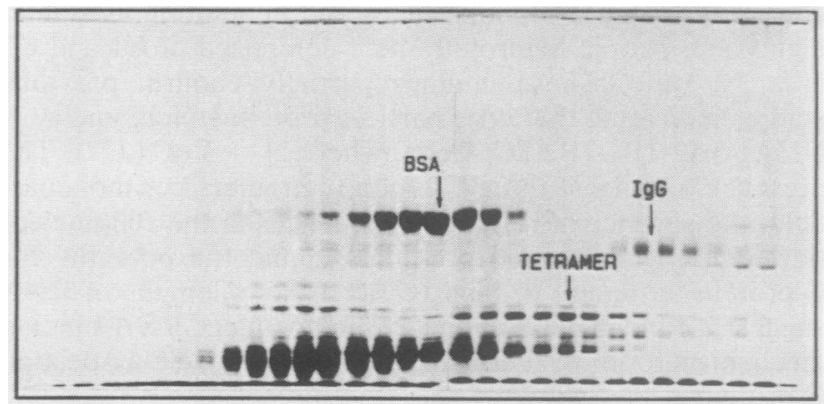

FIG. 2. Sedimentation of the C-protein complex released from monoparticles by digestion with RNase. Digested monoparticles and protein standards (BSA and immunoglobulin G) were combined and sedimented in a 5 to $20 \%$ sucrose gradient $(90 \mathrm{mM} \mathrm{NaCl})$. The Coomassie blue-stained SDS-PAGE gel reveals the distribution of protein in the gradient. Peak fractions and the sedimentation coefficient of the $C$ proteins were determined as described in the legend to Fig. 1.

polypeptides which comigrate with $\mathrm{C} 2$ in one-dimensional gels.

Direct evidence that $C$ protein is a tetramer was obtained through the strategy of Davies and Stark (14) for identifying the subunit structure of oligomeric proteins. The bifunctional, cleavable chemical protein cross-linking reagent DSP (26) was used in these studies. This reagent, in low concentrations, reacts with primary and secondary aliphatic amino groups at neutral $\mathrm{pH}$. Maximum cross-linking was observed at a DSP concentration of $0.2 \mathrm{mM}$ and at a protein concentration of $20 \mu \mathrm{g} / \mathrm{ml}$. A 5 to $15 \%$ gradient gel showing all of the cross-linked products is presented in Fig. 3A. The relative mobilities of the cross-linked products and their molecular weights are shown in Fig. 4. C proteins are known to migrate with an anomalously high molecular weight in SDS-PAGE (37), and in these gels the apparent molecular weight of $\mathrm{C} 1$ was 39,000 . Therefore, the molecular weights of the crosslinked products are consistent with the presence of dimers, trimers, and tetramers. As is often observed, the electrophoretic mobilities of oligomeric complexes are usually higher than expected on the basis of the molecular weights of the monomeric components because of space filling upon monomer association (10). The maintenance of retarded mobility seen here for dimers, trimers, and tetramers further supports the anisotropic nature of the C-protein tetramer (10). Tetramers were the largest cross-linked products observed (Fig. 4). These findings confirm hydrodynamic studies that indicate that $\mathrm{C}$ protein exists in solution as a tetramer.

The presence of multiple cross-linked products and their excellent resolution in gels (Fig. 3A) allowed us to determine that most, if not all, of the tetramers are composed of $(\mathrm{C} 1)_{3} \mathrm{C} 2$. The cross-linked products shown in Fig. 3A were electroeluted from excised gel slices, treated with BME to cleave the cross-links, and resolved by SDS-PAGE (Fig. 3B). Dimers composed of $(\mathrm{C} 1)_{2}$ and $\mathrm{C} 1 \mathrm{C} 2$ but not $(\mathrm{C} 2)_{2}$ were detected. Trimers composed of $(\mathrm{C} 1)_{3}$ and $(\mathrm{C} 1)_{2} \mathrm{C} 2$ but not $(\mathrm{C} 2)_{3}$ were detected. $(\mathrm{C} 1)_{3} \mathrm{C} 2$ tetramers were the largest cross-linked product obtained, and in other experiments in which the DSP concentration was raised, all of the $\mathrm{C}$ protein was converted to the tetramer (data not shown). If tetramers composed entirely of $\mathrm{C} 1$ or more than one copy of $\mathrm{C} 2$ exist, they were present at levels too low to detect. A summary of the data obtained from the hydrodynamic and cross-linking studies is shown in Table 1 . The distribution profile of $\mathrm{C}$ protein in the gel filtration and sedimentation experiments 

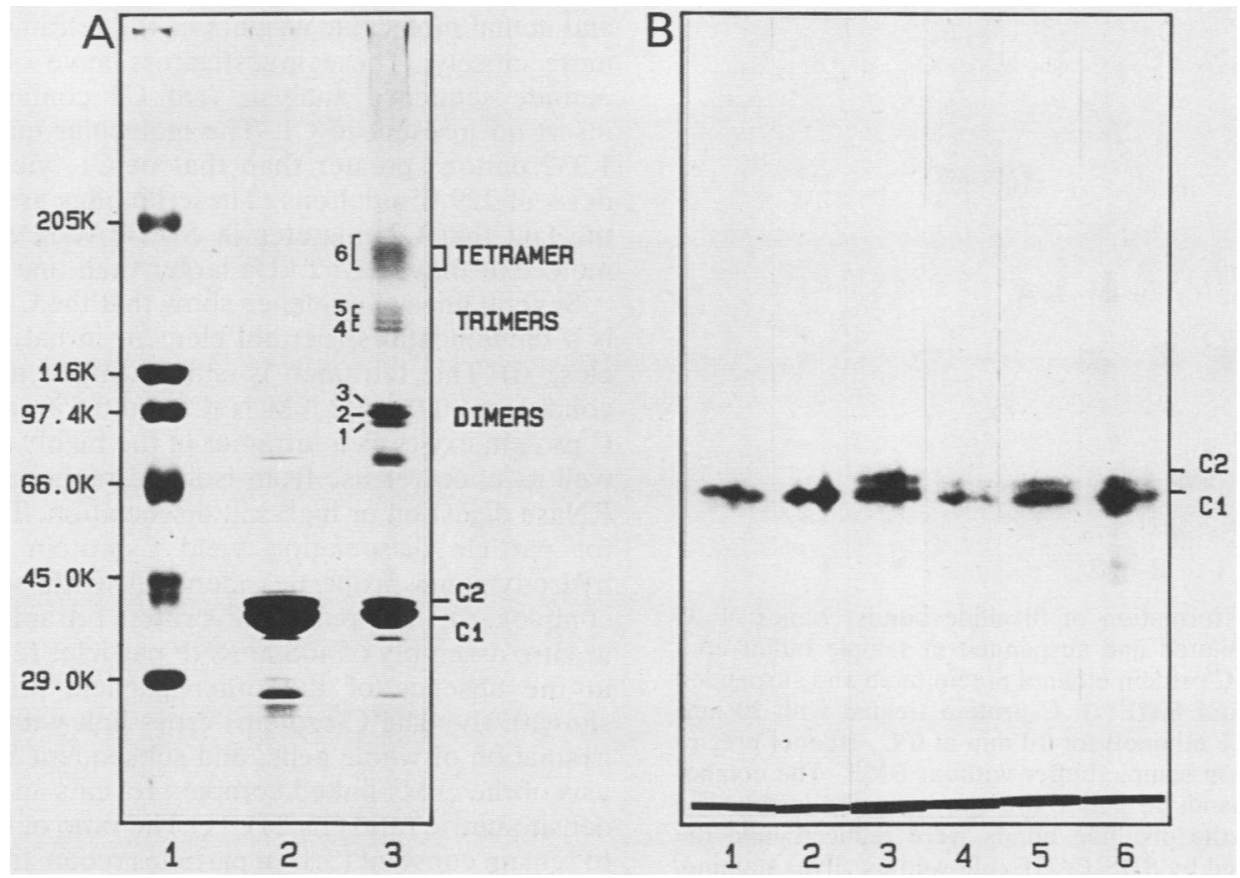

FIG. 3. DSP cross-linking of purified C protein. (A) SDS-PAGE (5 to $15 \%$ acrylamide gradient) of molecular weight standards (lane 1), non-cross-linked C protein (lane 2), and DSP-cross-linked C protein (lane 3). The dimer, trimer, and tetramer bands were identified by their molecular weights (see Fig. 4). (B) Composition of specific cross-linked products. Bands were excised, the cross-links were cleaved by reduction, and the products were separated in an $8.75 \%$ gel and silver stained. The bands marked 1 to 6 in lane 3 of panel $\mathrm{A}$ correspond to the numbered lanes in panel $B$.

did not reveal the presence of oligomers smaller than tetramers. This argues that the tetramer is not in equilibrium with smaller complexes and is consistent with the stability of the tetramer in extremes of ionic strength.

Protein $\mathrm{C} 1$ has a single cysteine at residue 46 (37). We tested the possibility that disulfide bonds could contribute to the stability of the tetramer (Fig. 5). When C protein was precipitated with ethanol and resolved in SDS-PAGE under nonreducing conditions, dimers were detected (Fig. 5, lane 2). Excision of the dimer bands, reduction, and SDS-PAGE under reducing conditions, indicated that the major band was a $(\mathrm{C} 1)_{2}$ dimer and the minor band was a $\mathrm{C} 1 \mathrm{C} 2$ dimer (Fig. 5, insert). No (C2) $)_{2}$ dimers were detected. If the $\mathrm{C}$ protein was treated with a sulfhydryl-modifying reagent ( $N$-ethylmaleimide) before ethanol precipitation, no dimers were detected (Fig. 5, lane 3). We therefore conclude that the dimers generated under nonreducing conditions are experimental artifacts and that no disulfide bridges exist between monomers in native $\mathrm{C}$-protein tetramers. This conclusion is supported by an experiment in which $\mathrm{C}$ protein was dialyzed extensively against $0.1 \%$ BME. Subsequent sedimentation in gradients containing $0.1 \% \mathrm{BME}$ and $1 \mathrm{M}$ $\mathrm{NaCl}$ revealed no effect on the sedimentation rate (data not shown).

Because the $\mathrm{C}$ proteins have a carboxy-terminal domain (residues 175 to 290) containing 20 aspartate and 21 glutamate residues, it is possible that these regions could form coordination complexes with divalent cations to stabilize the tetramer. To test this, $C$ protein was dialyzed extensively against buffered $10 \mathrm{mM}$ EDTA and then sedimented in a 5 to $10 \%$ sucrose gradient containing $1 \mathrm{mM}$ EDTA and $1 \mathrm{M} \mathrm{NaCl}$. The sedimentation coefficient was the same as that demon-

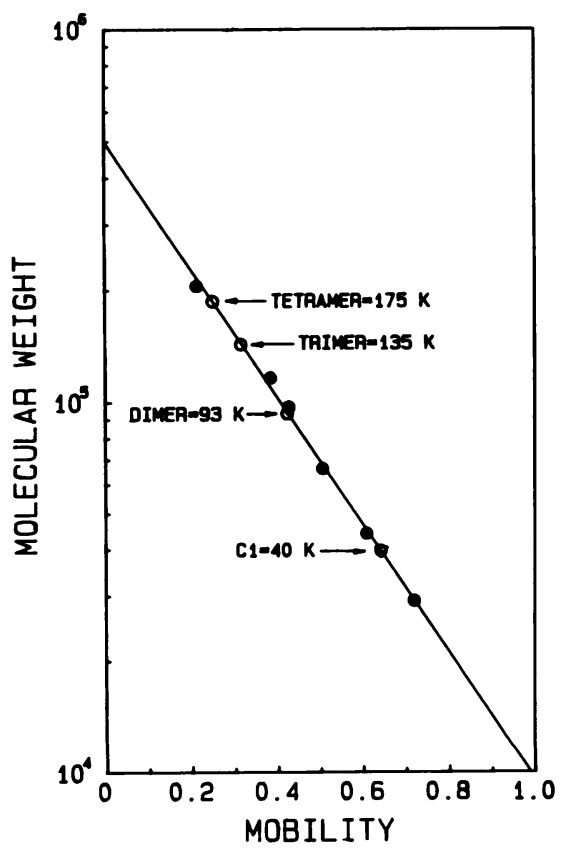

FIG. 4. Molecular weight determinations of the DSP-crosslinked C-protein complexes. The SDS-PAGE gel is shown in Fig. 3A. Protein mobility was measured relative to the bromophenol blue marker. The protein standards were myosin (molecular weight, $205,000), \beta$-galactosidase $(116,000)$, phosphorylase $(94,000)$, BSA $(67,000)$, ovalbumin $(45,000)$, and carbonic anhydrase $(29,000)$. 


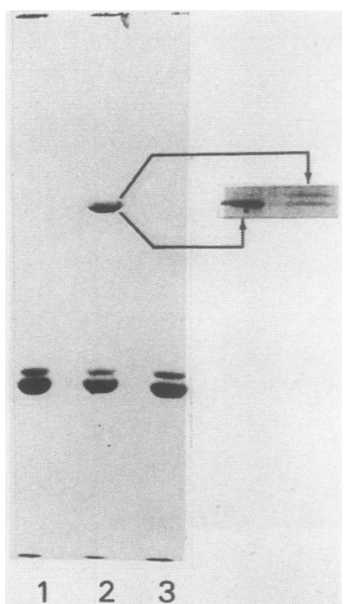

FIG. 5. Artifactual formation of disulfide bonds. Lanes: 1, C protein ethanol precipitated and suspended in sample buffer containing 0.1\% BME; 2, C protein ethanol precipitated and suspended in sample buffer without BME; 3, C protein treated with $20 \mathrm{mM}$ $\mathrm{N}$-ethylmaleimide $\left(80 \%\right.$ ethanol) for $10 \mathrm{~min}$ at $0^{\circ} \mathrm{C}$, ethanol precipitated, and suspended in sample buffer without BME. The compositions of the dimer bands in lane 2 are shown in the insert. The bands were excised, the disulfide bonds were reduced, and the products were separated by SDS-PAGE followed by silver staining.

strated for the tetramer in the absence of EDTA (data not shown).

Studies on the individual properties of $\mathrm{C} 1$ and $\mathrm{C} 2$ are complicated by the inability to separate these polypeptides by standard chromatographic techniques. In a previous study, isolated hnRNP particles were reversibly dissociated with $0.5 \%$ DOC (33). To determine whether this treatment disrupts hydrophobic interactions and dissociates the $\mathrm{C}$ protein tetramer, purified $\mathrm{C}$ protein was dialyzed to remove $\mathrm{Mg}^{2+}$, and solid sodium DOC was added to a final concentration of $0.5 \%$. This material was analyzed in 5 to $20 \%$ sucrose gradients containing $0.2 \%$ DOC, but dissociation of the tetramer was not observed (data not shown).

\section{DISCUSSION}

We have demonstrated that most, if not all, of the C proteins of HeLa 40S hnRNP particles exist in solution and in intact particles as a stable tetramer of $(\mathrm{C} 1)_{3} \mathrm{C} 2$. This confirms the protein cross-linking studies of Lothstein et al. (27), which indicated that the basic molar ratio of these polypeptides in hnRNP is $3: 1$, and it provides a structural basis for this observation. The approximate mass of monoparticles $\left(1.5 \times 10^{6}\right.$ to $\left.1.8 \times 10^{6}\right)(11,41)$ and the minimum core particle protein stoichiometry (3A1-3A2-1B1-1B2-3C1$1 \mathrm{C} 2)$ indicate that the monoparticles must contain three or four C-protein tetramers. While several lines of evidence suggest that $40 \mathrm{~S}$ monoparticles are regular structures which package $700 \pm 20$ nucleotides of pre-mRNA $(13,33,39$; LeStourgeon et al., in press), the location of the C-protein tetramers along the packaged length of RNA is unknown.

The values determined here for the Stokes radius $(6.2 \mathrm{~nm})$, sedimentation coefficient (5.8S), and partical specific volume $\left(0.70 \mathrm{~cm}^{3} / \mathrm{g}\right)$ of the C-protein tetramer yield a calculated molecular weight of 135,500 . The close agreement of this value with the sequence-determined mass of a tetramer composed entirely of $\mathrm{C} 1(125,725)$ lends credibility to the above values. Based on recent findings (B. M. Merrill and
K. R. Williams, personal communication), the calculated and actual molecular weights of the tetramer, in fact, agree more closely. These investigators have observed through peptide sequence analysis that $\mathrm{C} 2$ contains a 13-residue insert not present in $\mathrm{C} 1$. The molecular mass of $\mathrm{C} 2$ is thus 1,332 daltons greater than that of $\mathrm{C} 1$, yielding a tetramer mass of 129,056 daltons. These findings are consistent with the fact that $\mathrm{C} 2$ migrates in SDS-PAGE with an apparent molecular mass 1 to $2 \mathrm{kDa}$ larger than that of $\mathrm{C} 1(5,7)$.

Several lines of evidence show that the $\mathrm{C}$-protein tetramer is a fundamental structural element in native hnRNP particles. (i) The tetramer is stable under a wide range of conditions (0.09 to $2.0 \mathrm{M} \mathrm{NaCl}$ and $0.5 \%$ sodium DOC). (ii) $\mathrm{C}$ protein exists as a tetramer in the highly purified state, as well as upon release from isolated monoparticles by either RNase digestion or high-salt dissociation. These procedures for particle dissociation yield C-protein complexes with hydrodynamic properties identical to those of the purified complex. (iii) The purified C-protein tetramer participates in in vitro assembly of $40 \mathrm{~S}$ hnRNP particles (2) and binds RNA in the absence of the other particle proteins (data not shown). (iv) The C-proteins cross-link with RNA upon UV irradiation of whole cells, and subsequent SDS-PAGE analysis of the cross-linked complex reveals an approximate 3:1 densitometric ratio (15-17). (v) The ratio of $C 1$ to $C 2$ appears to remain constant (3:1) in particles reconstituted in RNAs of various lengths (14). This suggests that $C$-protein tetramers and not single polypeptides participate in particle assembly. (vi) Previous protein-cross-linking studies performed on intact isolated $40 \mathrm{~S}$ monoparticles with dimethyl-3,3'-dithiobispropionimidate revealed fundamental trimeric associations of $\mathrm{C} 1$ and small amounts of the C-protein tetramer (27).

As originally defined (5), the $\mathrm{C}$ proteins of HeLa cell hnRNP were the two major polypeptides of $40 \mathrm{~S}$ core particles which (i) bind RNA in a salt-resistant manner, (ii) have acidic isoelectric points, (iii) migrate in SDS-PAGE with approximate molecular masses of 42 and 44 kilodaltons, and (iv) are the major phosphorylated species among the six core particle proteins (21). More recent studies have also shown that among the six core proteins, the $\mathrm{C}$ proteins most readily cross-link with RNA upon UV irradiation $(7,13)$ and that both $\mathrm{C} 1$ and $\mathrm{C} 2$ are specifically bound by the monoclonal antibodies termed $2 \mathrm{~B} 12$ and $4 \mathrm{~F} 4(8,17)$. This report adds the additional characteristic of their tetrameric association.

A final point deserving considration is the anisotropic nature of the $\mathrm{C}$-protein tetramer. The tetramer eluted from gel filtration columns with an apparent molecular weight of nearly $0.5 \times 10^{6}$ and it had a frictional ratio of 2.0. This suggests that the tetramer is a prolate ellipsoid with an axial ratio of 20 or an oblate ellipsoid with an axial ratio of 30 (19). While this analysis does not allow one to predict the actual shape of the tetramer, it is clearly not an efficiently folded spherical structure. The underlying significance here bears on the spatial orientation of the RNA-binding domains. In the sequence analysis of Swanson et al. (37), a putative RNA-binding sequence common to several RNA-binding proteins was identified in the amino-terminal region of $\mathrm{C} 1$. Thus, the spatial arrangement of the four RNA-binding domains may determine the length of RNA contacted by a single tetramer. If the binding domains are maximally separated (as on the surface of a tetrahedral structure or spaced in a tandem association of polypeptides), a complex with a Stokes radius of $6.2 \mathrm{~nm}$ might contact an RNA fragment with as many as 115 nucleotides. In this context, it can be noted that the single-stranded binding protein of Escherichia coli (EcoSSB) binds 65 nucleotides at $0.2 \mathrm{M}$ salt and is a highly 
stable tetramer with one-third less mass and one-half the Stokes radius of the C-protein tetramer (6). Because the C proteins make up one-third of the core proteins of $40 \mathrm{~S}$ monoparticles, representing at least three C-protein tetramers, it is likely that much of the packaged 700-nucleotide pre-mRNA moiety (13) is associated with $C$ protein in a sequence-independent manner.

\section{ACKNOWLEDGMENTS}

We thank Robley Williams, Jr., of this department for helpful discussions

The research was supported by National Science Foundation grant DCB 85-12035 and by Vanderbilt University grant BRSG507-RR07201 to W.M.L. and by National Science Foundation grant DCB 84-17613 to D.L.F.

\section{LITERATURE CITED}

1. Ackers, G. K. 1964. Molecular exclusion and restricted diffusion processes in molecular sieve chromatography. Biochemistry 3:723-730.

2. Barnett, S. F., W. M. LeStourgeon, and D. L. Friedman. 1988. Rapid purification of native $C$ protein from nuclear ribonucleoprotein particles. J. Biochem. Biophys. Methods 16:87-98.

3. Beyer, A. L. 1983. Ultrastructural analysis of the ribonucleoprotein structure of nascent hnRNA. Mol. Biol. Rep. 9:49-58.

4. Beyer, A. L., A. H. Bouton, and O. L. Miller, Jr. 1981. Correlation of hnRNP structure and nascent transcriptive cleavage. Cell 26:155-163.

5. Beyer, A. L., M. E. Christensen, B. W. Walker, and W. M. LeStourgeon. 1977. Identification and characterization of the packaging proteins of core $40 \mathrm{~S}$ hnRNP particles. Cell 11: 127-138.

6. Chase, J. W., and K. R. Williams. 1986. Single-stranded DNA binding proteins required for DNA replication. Annu. Rev. Biochem. 55:103-136.

7. Choi, Y. D., and G. Dreyfuss. 1984. Isolation of the heterogeneous nuclear RNA- ribonucleoprotein complex (hnRNP): a unique supramolecular assembly. Proc. Natl. Acad. Sci. USA 81:7471-7475.

8. Choi, Y. D., and G. Dreyfuss. 1984. Monoclonal antibody characterization of the $\mathrm{C}$ proteins of heterogeneous nuclear ribonucleoprotein complexes in vertebrate cells. J. Cell Biol. 99:1997-2004.

9. Choi, Y. D., P. J. Grabowski, P. A. Sharp, and G. Dreyfuss. 1986. Heterogeneous nuclear ribonucleoproteins: role in RNA splicing. Science 231:1534-1539.

10. Chrambach, A., and D. Rodbard. 1971. Polyacrylamide gel electrophoresis. Science 172:440-451.

11. Chung, S. Y., and J. Wooley. 1986. Set of novel, conserved proteins fold pre-messenger RNA into ribonucleosomes. Proteins Struct. Funct. Genet. 1:195-210.

12. Cohn, E. J., and J. T. Edsall. 1943. Proteins, amino acids and peptides as ions and dipolar ions, p. 370-381. Reinhold Publishing Corp., New York.

13. Conway, G., J. Wooley, T. Bibring, and W. M. LeStourgeon. 1988. Ribonucleoproteins package 700 nucleotides of premRNA into a repeating array of regular particles. Mol. Cell. Biol. 8:2884-2895.

14. Davies, G. E., and G. R. Stark. 1970. Use of dimethyl suberimidate, a cross-linking reagent, in studying the subunit structure of oligomeric proteins. Proc. Natl. Acad. Sci. USA 48:562-570.

15. Dreyfuss, G. 1986. Structure and function of nuclear and cytoplasmic ribonucleoprotein particles. Annu. Rev. Cell. Biol. 2:457-495.

16. Dreyfuss, G., S. A. Adam, and Y. D. Choi. 1984. Physical change in cytoplasmic messenger ribonucleoproteins in cells treated with inhibitors of mRNA transcription. Mol. Cell. Biol. 4: 415-423.

17. Dreyfuss, G., Y. D. Choi, and S. A. Adam. 1984. Characterization of heterogeneous nuclear RNA-protein complexes in vivo with monoclonal antibodies. Mol. Cell. Biol. 4:1104-1114.

18. Fenner, C., R. R. Traut, D. T. Mason, and J. Wikman-Coffelt. 1975. Quantitation of Coomassie blue stained proteins in polyacrylamide gels based on analyses of eluted dye. Anal. Biochem. 63:595-602.

19. Freifelder, D. 1982. Physical biochemistry: applications to biochemistry and molecular biology, p. 460-467. W. H. Freeman \& Co., New York.

20. Goswami, P., and C. J. Goldenberg. 1988. Intron sequences and the length of the downstream second exon affect the binding of proteins in an in vitro splicing reaction. Nucleic Acids Res. 16:4995-5011.

21. Holcomb, E. R., and D. L. Friedman. 1984. Phosphorylation of the C-proteins of HeLa cell hnRNP particles. Involvement of a casein kinase II-type enzyme. J. Biol. Chem. 259:31-40.

22. Knowler, J. T. 1983. An assessment of the evidence for the role of ribonucleoprotein particles in the maturation of eukaryote mRNA. Int. Rev. Cytol. 84:103-153.

23. Laemmli, U. K. 1970. Cleavage of structural proteins during the assembly of the head of bacteriophage T4. Nature (London) 227:680-685.

24. LeStourgeon, W. M., A. L. Beyer, M. E. Christensen, B. W. Walker, S. M. Poupore, and L. P. Daniels. 1977. The packaging proteins of core hnRNP particles and the maintenance of proliferative cell states. Cold Spring Harbor Symp. Quant. Biol. 42:885-898.

25. LeStourgeon, W. M., L. Lothstein, B. W. Walker, and A. L. Beyer. 1981. The composition and general topology of RNA and protein in monomer 40S ribonucleoprotein particles, p. 49-87. In $\mathrm{H}$. Busch (ed.), The cell nucleus. Academic Press, Inc., New York.

26. Lomant, A. J., and G. Fairbanks. 1976. Chemical probes of extended biological structures: synthesis and properties of the cleavable protein cross-linking reagent $\left[{ }^{35}\right.$ S $]$ dithiobis(succinimidyl propionate). J. Mol. Biol. 104:243-261.

27. Lothstein, L., H. P. Arenstorf, S. Chung, B. W. Walker, J. C. Wooley, and W. M. LeStourgeon. 1985. General organization of protein in HeLa 40S nuclear ribonucleoprotein particles. J. Cell Biol. 100:1570-1581.

28. Lowry, O. H., N. J. Rosebrough, A. L. Farr, and R. J. Randall. 1951. Protein measurement with the Folin phenol reagent. J. Biol. Chem. 193:265-275.

29. Martin, R. G., and B. N. Ames. 1961. A method for determining the sedimentation behavior of enzymes: application to protein mixtures. J. Biol. Chem. 236:1372-1379.

30. Osheim, Y. N., O. L. Miller, Jr., and A. L. Beyer. 1985. RNP particles and splice junction sequences in Drosophila chorion transcripts. Cell 43:143-151.

31. Peterson, G. L. 1977. A simplification of the protein assay method of Lowry et al. which is more generally applicable. Anal. Biochem. 83:346-356.

32. Pinol-Roma, S., Y. D. Choi, M. J. Matunis, and G. Dreyfuss. 1988. Immunopurification of heterogeneous nuclear ribonucleoprotein particles reveals an assortment of RNA-binding proteins. Genes Dev. 2:215-227.

33. Pullman, J. M., and T. E. Martin. 1983. Reconstitution of nucleoprotein complexes with mammalian heterogeneous nuclear ribonucleoprotein (hnRNP) core proteins. J. Cell Biol. 97:99-111.

34. Sekeris, C. E., and J. Niessing. 1975. Evidence for the existence of a structural RNA component in the nuclear ribonucleoprotein particles containing heterogeneous RNA. Biochem. Biophys. Res. Commun. 62:642-650.

35. Sierakowska, H., W. Szer, P. J. Furdon, and R. Kole. 1986. Antibodies to hnRNP core proteins inhibit in vitro splicing of human $\beta$-globin pre-mRNA. Nucleic Acids Res. 11:1475-1489.

36. Swanson, M. S., and G. Dreyfuss. 1988. RNA binding specificity of hnRNP proteins: a subset bind to the $3^{\prime}$ end of introns. EMBO J. 11:12-24.

37. Swanson, M. S., T. Y. Nakagawa, K. LeVan, and G. Dreyfuss. 1987. Primary structure of human nuclear ribonucleoprotein particle $\mathrm{C}$ proteins: conservation of sequence and domain structures in heterogeneous nuclear RNA, mRNA, and pre- 
RNA-binding proteins. Mol. Cell. Biol. 7:1731-1739.

38. Tsanev, R. G., and L. P. Djondurov. 1982. Ultrastructure of free ribonucleoprotein complexes in spread mammalian nuclei. $\mathrm{J}$. Cell Biol. 94:662-666.

39. Wilk, H. E., G. Angeli, and K. P. Schafer. 1983. In vitro reconstitution of $35 \mathrm{~S}$ ribonucleoprotein complexes. Biochemistry 22:4592-4600.
40. Wilk, H. E., H. Werr, D. Friedrich, H. H. Kiltz, and K. P. Schaefer. 1985. The core proteins of $35 \mathrm{~S}$ hnRNP complexes: characterization of 9 different species. Eur. J. Biochem. 146: $71-81$.

41. Wooley, J., S. Y. Chang, J. Wall, and W. M. LeStourgeon. 1986. Architecture of pre-messenger, nuclear ribonucleoprotein monoparticles. Biophys. J. 49:17-19. 